\title{
Conservation of Nature and Natural Resources through Spirituality
}

\author{
Chandra Prakash Kala* \\ Ecosystem \& Environment Management, Indian Institute of Forest Management, Nehru Nagar, Bhopal, Madhya Pradesh, India \\ *Corresponding author: cpkala@yahoo.co.uk
}

\begin{abstract}
Conservation of nature and natural resources has been a much challenging task in the present state of affairs where economy prevails over ecology. International treaties and conventions are signed and policies, laws and Acts have been enacted by the countries across the world, however, hostilities remain while applying the protected area policies which largely deprive indigenous communities from their traditional rights. It hurts their feelings and hence changes their behaviour, which impacts the objective, negatively. Historically, religion being a product of feelings and beliefs has been used as a powerful tool for nature conservation. Making age-old religious entities such as sacred landscapes, sacred groves and sacred species by various cultural groups are the live manifestations of historical, cultural and emotional attachment of human beings with nature and natural resources. The philosophy of religion can continue to be used as a powerful tool for mitigating negative impacts of current anthropogenic pressures on the nature and its resources. With this background, the present review aims to analyse various practices of nature and natural resource conservation as embedded in the religions.
\end{abstract}

Keywords: nature, natural resources, conservation, religion, sacred landscape, sacred grove

Cite This Article: Chandra Prakash Kala, "Conservation of Nature and Natural Resources through Spirituality." Applied Ecology and Environmental Sciences, vol. 5, no. 2 (2017): 24-34. doi: 10.12691/aees-5-2-1..

\section{Introduction}

Feelings and desires are the motivational forces behind all human endeavours and human creation [1], and the similar forces are believed to evolve the process of nature conservation [2,3]. Religion being a product of feelings and beliefs, historically this instrument is used as a powerful tool for nature conservation. The sense of belonging in nature has been created by performing various rituals, and many of them are still practiced today by various religious sects [4]. The diverse components of nature, whether living or non-living, have been attracting human curiosities since time immemorial that is reflected in the religious symbols of such components. Being a source of joy and inspiration for inquisitive minds, from poets to philosophers and knowledge-seekers to knowledge-providers, the nature's components have been defined in different perspectives. There are ample examples which indicate that not only plant and animal species but also water, air and land represent various gods and goddesses, apart from their materialistic uses. In traditional landscape, the sacred areas act as de facto protected areas [5]. However, it is felt that the religious norms and ways of nature conservation have often been neglected, misunderstood, or purposefully misrepresented with due course of time $[6,7]$.

The increasing disconnection from nature due to urbanization and exponential growth of human-induced stresses on natural ecosystems cause severe environmental degradation and loss of biodiversity $[8,9,10]$. The ongoing climate change related impacts on various ecosystems are also the subject of grave concern when the nature is already reeling under various stresses [11]. The philosophy of religion and its belief system that helped in saving the world in the past can continue to be used as a powerful tool for mitigating the negative impacts of current anthropogenic pressures [12]. There are reports which indicate that cultural and religious values are often more acceptable to the society in comparison to the legislations or regulations [13]. The growing interests among society in spiritual ecology [14], which focuses on the interrelationship between religions and environment, may help to address various environmental issues and problems within the realm of religion.

Nature worship as a predominant form of religion is not yet studied well with respect to conservation of natural resources. The concept of nature conservation is embedded in many religions, including Hinduism and Buddhism. In the era of climate change and degradation of nature and natural resources due to several reasons, predominately anthropogenic, it is necessary to explore ways for their conservation for posterity. Besides, the long-established belief systems need to be critically analysed for their better understanding and applications across the board. With this background, the present study aims to analyse various practices of nature and natural resource conservation as embedded in the religions. The study further focuses on the ways to simulate the biodiversity conservation model institutionalized on the religious philosophies. 


\section{Methodology}

Extensive literature survey was carried out for compilation of data on various traditional practices, as adopted by different cultural groups, for nature and natural resource conservation. The relevant materials were screened from the large set of data gathered by consulting books, scientific reports, conference materials, scientific journals and online search engines. Besides, the first hand information on the nature and natural resource conservation and management has also been collected and compiled by approaching different cultural groups within India. The broad categories of collected information, such as, sacred landscape, sacred grove and sacred species were made for analytical purpose.

\section{Result and Discussion}

\subsection{Sacred Landscape}

The whole earth is the mother to the believers of Hinduism, which indicates the gravity of ethics for nature conservation in religion. Islam teaches that the prime responsibility of saving the earth and its natural resources is vested with humans being the agents of the God [15]. Jerusalem is the holy land for Christians and the third holiest city for the Muslims [16]. From Classical to Roman time people perceived that the land was owned by the gods hence it had to be used judiciously. And in present decade, the Pope Francis, the $266^{\text {th }}$ and current Pope of the Roman Catholic Church calls for respect and protection of the entire creation which God has entrusted to man [17].

Historically, a sort of hierarchy of sacredness of landscapes was made, which was embedded within the religious philosophy. The land of gods was considered as a kind of invulnerable and holy territory [18]. The Roman and Greek landscapes, traditionally, were dotted with sacred places generally having groves, and Romans often personified these trees as the 'Forest King' [19]. The ancient Celts, a European cultural group, worship nature and belief that nature alive as the same creative life force that humans share. Nature spirits animated springs, river, forests and mountains [20]. In Hinduism, five elements such as earth, space, air, water and fire have special mention and each element is worshipped as a deity. The Greek and Romans have many common gods. Greeks believe wind as a god and hence celebrate ceremonies on the hill tops [21]. The followers of Islam believe that the al-Buraq site and the Dome of the Rock in Jerusalem are some of the holiest sites on the earth, apart from Mecca and Medina, because of their association with holy Prophet Muhammad's journey to heaven [16].

Table 1. Some major mountains across the world considered sacred by different ethnic groups

\begin{tabular}{|c|c|c|c|c|}
\hline S. No. & Cultural group & Holy mountains & Religious characteristics & Ref. \\
\hline 1 & $\begin{array}{l}\text { Buddhism and } \\
\text { Shintoism }\end{array}$ & Mount Fuji in Japan & $\begin{array}{l}\text { It is believed as a fire god, a Shinto } \\
\text { goddess and Dainichi Nyorai }\end{array}$ & Earhart, 1989 \\
\hline 2 & Christian pilgrims & $\begin{array}{l}\text { Mount of the Holy Cross in Colorado, Rocky } \\
\text { Mountains }\end{array}$ & $\begin{array}{l}\text { Christian pilgrims visit it as they belief } \\
\text { that a giant cross is hidden here }\end{array}$ & Black, 2008 \\
\hline 3 & Hebrew & Mount Nebo in Jordan & $\begin{array}{l}\text { It is associated with Moses-a Hebrew } \\
\text { prophet }\end{array}$ & $\begin{array}{l}\text { Harahsheh et al., } \\
2007\end{array}$ \\
\hline 4 & Christian pilgrims & Mount Croagh Patrick in Ireland & An abode of deity Crom Dubh & Harbison, 1992 \\
\hline 5 & $\begin{array}{l}\text { Native American } \\
\text { tribes }\end{array}$ & San Francisco Peaks in Arizona & $\begin{array}{l}\text { It is considered sacred by about } 13 \\
\text { tribes including, Hopi, Navajo, } \\
\text { Hualapai, Zuni and } 5 \text { Apache tribe }\end{array}$ & Lane, 2001 \\
\hline 6 & $\begin{array}{l}\text { Aztecs, Spanish } \\
\text { missionaries }\end{array}$ & $\begin{array}{l}\text { Citlaltepetl (Star Mountain), Popocatepetl } \\
\text { (Smoking Mountain), and Iztaccihuatl } \\
\text { (Sleeping Woman) in Mexico }\end{array}$ & $\begin{array}{l}\text { Named after legendary } \\
\text { deities }\end{array}$ & Bassler, 1989 \\
\hline 7 & $\begin{array}{l}\text { Lakota and } \\
\text { Cheyenne and other } \\
\text { tribes }\end{array}$ & Inyan Kara in Black Hills of Dakota & $\begin{array}{l}\text { Dwelling place of thunder gods to the } \\
\text { Lakota and Cheyenne and other tribes }\end{array}$ & Sundstrom, 1997 \\
\hline 8 & Taranaki tribe & $\begin{array}{l}\text { Mount Taranaki also known as Mount } \\
\text { Egmont in New Zealand }\end{array}$ & Sacred mountains & Knight, 2009 \\
\hline 9 & Greeks & Mount Olympus in Greek & $\begin{array}{l}\text { It is believed an abode of } 12 \text { Olympian } \\
\text { gods }\end{array}$ & Woff, 2003 \\
\hline 10 & $\begin{array}{l}\text { Witness Christian, } \\
\text { Jewish and Islamic } \\
\text { hagiography }\end{array}$ & Mount Sinai in Egypt & $\begin{array}{l}\text { Believers of these religions consider } \\
\text { Mount Sinai the place where Moses } \\
\text { received the Ten Commandments }\end{array}$ & Shackley, 1998 \\
\hline 11 & Hindus & Kailash, Neelkanth, and Trishul in Himalaya & $\begin{array}{l}\text { Kailash is abode of the Shiva, } \\
\text { Neelkanth is Shiva's symbol and } \\
\text { Trishul is weapon }\end{array}$ & Kala, 2010a \\
\hline 12 & Hindus & Nanda Devi in India & Consort of Lord Shiva & Kala, 2010a, 2015b \\
\hline 13 & Nepalese & Sagarmatha or Mount Everest & Goddess of the sky & Armour, 2006 \\
\hline 14 & Tibetans & Chomolangma or Mount Everest & Goddess mother of the universe & Armour, 2006 \\
\hline 15 & Tibetan Buddhists & Mount Kawa Karpo in eastern Himalaya & $\begin{array}{l}\text { Medicine Mountains, is one of the most } \\
\text { sacred mountains }\end{array}$ & $\begin{array}{l}\text { Anderson et. al., } \\
2005\end{array}$ \\
\hline
\end{tabular}


Traditionally, many mountain peaks across the world have been venerated as the dwelling places of gods and goddesses (Table 1). In Greek mythology, the Mount Olympus which is the tallest mountain in Greece is believed to be the home of twelve Olympian gods, including Zeus (Jupiter), Hera (Juno), Poseidon (Neptune), Athena and Apollo [21]. The snow capped Mount Fuji in Japan is sacred to both Buddhism and Shintoism as it is venerated as the home of fire god, a Shinto goddess and Dainichi Nyorai - the Great Sun Buddha [22]. The Mount Agung in Bali is considered sacred by the Balinese. Mount of the Holy Cross in Colorado is a popular Christian pilgrimage site as it is believed that a giant cross is hidden deep in the Rocky Mountains [23]. Mount Nebo in Jordan being associated with Moses - a Hebrew prophet - is sacred to the communities [24].

Mount Croagh Patrick in Ireland being considered to be an abode of deity Crom Dubh is venerated and hence visited by thousands of pilgrims, annually [25]. The San Francisco Peaks in Arizona is the most sacred site for more than a dozen of Native American tribes who consider this volcanic chain to be sacred [26]. Popocatepel in Mexico is another volcanic peak which remains sacred for the Spanish missionaries. The Inyan Kara in Black Hills of Dakota is believed to be the dwelling place of thunder gods to the Lakota and Cheyenne and other tribes [27]. The Mount Taranaki also known as Mount Egmont in New Zealand is of special significance to the Taranaki tribe [28]. The Mount Sinai in Egypt is the witness of Christian, Jewish and Islamic hagiography as the believers of these religions consider Mount Sinai the place where Moses received the Ten Commandments [29].

Likewise in Indian subcontinent, traditionally, many mountain peaks and wilderness areas are venerated as the dwellings of deities, demons and fairies. Many mountain peaks symbolize the gods and the goddesses hence people worship these majestic peaks. The Himalaya has been venerated by communities since antiquity and hence visited by a large number of pilgrims for paying tribute [30]. Numerous mountain peaks of the Himalaya such as Kailash, Nanda Devi, Neelkanth, Trishul, Gaura and Om mountains are worshipped as deities by various communities living not only in the Himalayan region but far away from the Himalaya. Mount Everest, the world's highest mountain peak, is called as the Chomolangma (goddess mother of the universe) by Tibetans and Sagarmatha (goddess of the sky) by the Nepalese [31]. Being sacred and worshipped from centuries these mountain landscapes having extremely valuable biodiversity remain protected from centuries by their association with religion [4].

In eastern Himalaya, the Mount Kawa Karpo, literally means Medicine Mountains, is one of the most sacred mountains to the Tibetan Buddhists. In comparison to non-sacred sites the sacred sites close to the villages within Kawa Karpo have higher overall species richness, diversity and endemism hence such sacred sites are ecologically and ethnobotanically unique [32]. Besides, the useful and old growth plants are thrived more in the sacred sites of Kawa Karpo [33].

Apart from the land, almost all the lakes in the Himalaya are regarded as sacred (Figure 1). The sanctity of innumerable lakes across its mountain range is described by local communities in numerous folklores. The flora and fauna in these lakes are saved due to such belief systems. The running waters also present unique patterns of distribution of biological diversity among taxonomic groups and among regions. Although invertebrate diversity is incompletely catalogued, generally it exceeds vertebrate diversity at any locale. In contrast with the fishes and terrestrial insects, the diversity of insects in tropical streams does not appear to exceed that found in temperate streams [34].

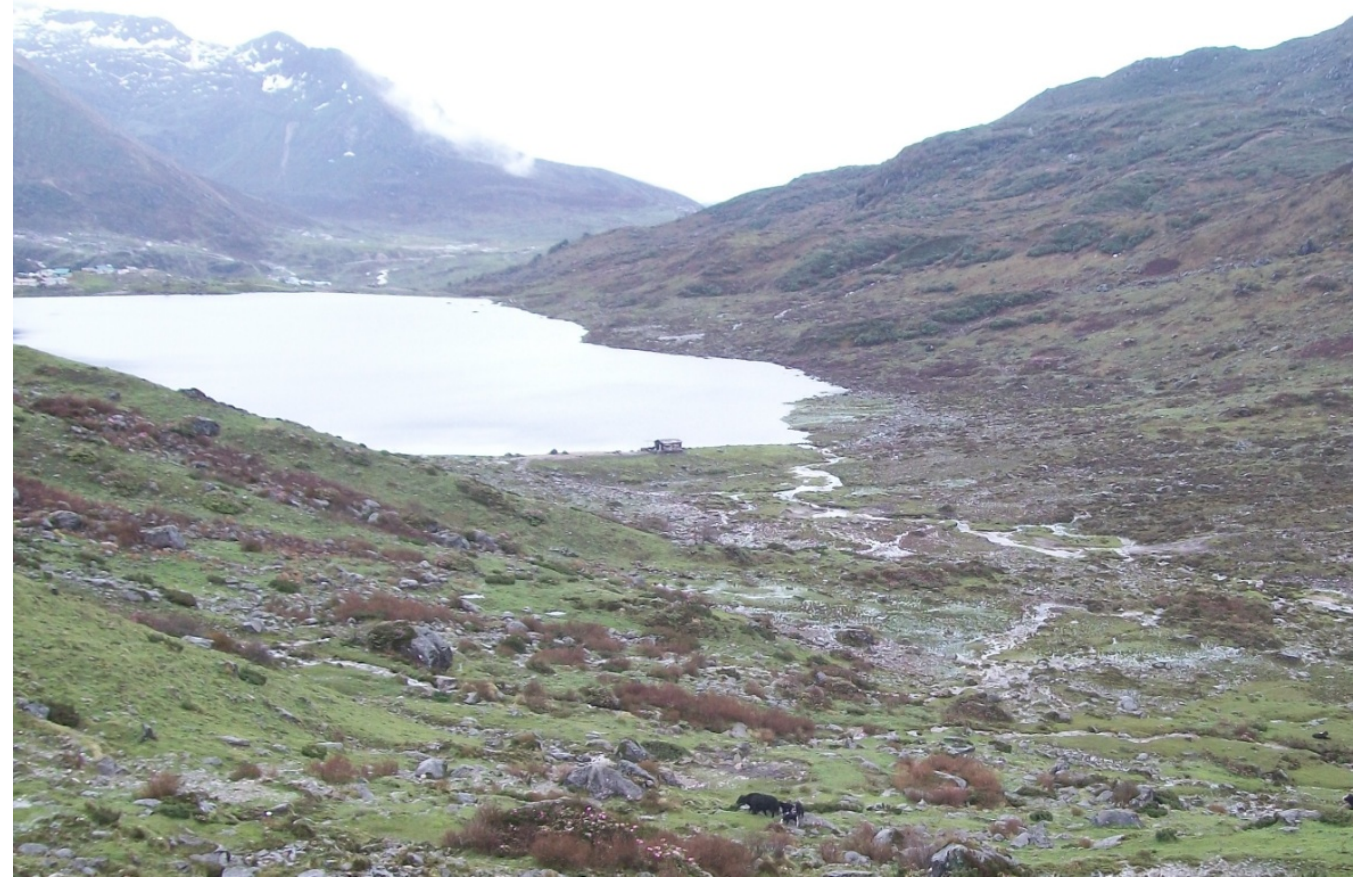

Figure 1. Sacred landscape and sacred lake in the Sikkim Himalayas - Photo by Chandra Prakash Kala 
The land, tributaries of many sacred rivers and various natural and man-managed ecosystems, all together represent a set of interconnected ecosystems. One of the most sacred rivers in southwest Asia is the Jordan River, in which John the Baptist baptized the Jesus [35]. Being celebrated in the holy books of Judaism, Christianity, and Islam a large number of pilgrims visit the Jordan River, annually [36,37]. In Indian sub-continent, the Ganga is venerated a holy river by Hindus, which originates from the Gaumukh glacier of the Himalaya and wherever the Ganga traverses that landscape is also considered sacred [30]. There are many well-known traditional religious institutions in the Himalaya and elsewhere (e.g. Badrinath, Kedarnath, Yamunotri, Gangotri and Amarnath), which held up high and maintain the values of these sacred landscapes. The sanctity of these landscape helps in conservation of nature and biodiversity.

\subsection{Sacred Grove}

The evolution of sacred grove concept is mainly based on the strong interactions of society with the surrounding forested areas, which secure the group of species and natural habitats in the long run. A sacred grove is a forested area that is associated with deities, ancestral spirits, rituals and taboos, culturally $[38,39]$. Such groves are the live manifestations of historical, cultural and emotional attachment of human beings with forests. They unify rural communities religiously, culturally and socially [40].

The sacred grove concept had adopted by various indigenous communities worldwide, such as, aboriginals of Australia, Caucasus Mountains community, ancient Slavic people, German tribes [41], Greeks, Romans and Kikuyu of Africa [10], people of China, Japan, and Native America [42], Mbeere tribe of East Africa [43], and Khanti tribe of Siberia [44]. Before the spread of Christianity and Islam the sacred groves covered much of the Middle East and Europe. The sacred grove concept is still relevant and exists today, especially in many parts of Asia, Africa and Mexico [45].

In India, over 13,720 sacred groves have been enlisted [46] that exist across diverse topography and climatic conditions from south to north however the actual number is thought to be much larger than that [4]. Sacred groves ranges from few square meters (Figure 2) to many hectares are known by different names at different places in India, such as 'Devray' in Maharastra, 'Devarkand' and 'Siddarvanam' in Karnataka, 'Oraans', 'Kenkari', 'Malvan' and 'Yogmaya' in Rajasthan, Saran in Chhattisgarh and 'Saranya' in Bihar $[40,47,48]$. In tribal region of Jharkhand and Orissa sacred groves are popularly known as Jaher [49]. Many villages in the mountains above seacoast in south India, where shifting cultivation was practiced in the past, do have sacred groves [50]. Sacred groves shelter habitats of many threatened plant and animal species. The traditional customary rules prohibit felling of trees and killing of animals in the sacred groves, which help to pave the way for conservation of biodiversity in such areas [51].

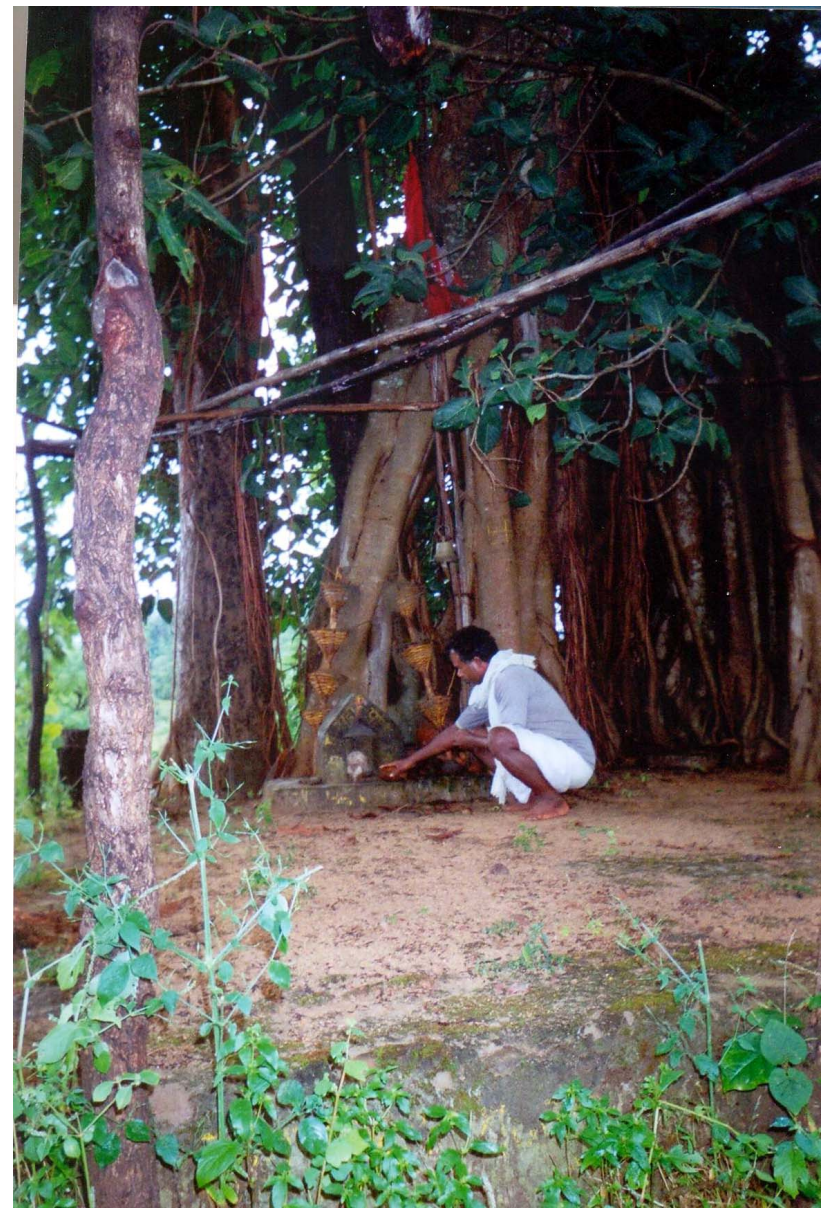

Figure 2. Sacred grove in central India - Photo by Chandra Prakash Kala

Menominee tribes of the United States share a similar belief along with other indigenous communities of North America that all nonhumans have spirit and also the entire forest has spirit. This belief system has made the community to respect every creature and the entire forest [52]. In Zimbabwe, the loss of forests remains considerably less in the forests considered as sacred forests, which reflects that spiritual values influence human behaviour and hence help in protecting the nature and natural resources [53]. Besides Zimbabwe, Ghana, Nigeria, and Syria, the sacred groves are also reported from Turkey and Japan [38].

According to the unwritten Constitution of the community, generally, no one can destroy or cut trees in the sacred groves. Collection of dried wood is also not allowed. The trees inside the sacred groves are not touched by the axe in India except when the wood is required for the repair of religious buildings [54]. Forest is always considered sacred by the indigenous communities in India, and they believe that forest gives power to their deities. In some indigenous communities, especially during festivals, the power of deity is brought to the village temple through rituals and once festival is over the same power is returned to the forest again by performing some specific rituals [55]. These indigenous communities have created various beliefs through their experiences, which are molded and reflected in their folklores. Being a powerful tool for communication folklore plays an 
important role in spreading knowledge to the posterity. Sacred groves not only unify communities but also create a forum for festivals, dialogues and other social events.

Sacred groves have become the last refuge for many threatened species. In Kodagu region of Western Ghats, a biodiversity hotspot, some threatened tree species such as Actinodaphne lawsonii, Hopea ponga, Madhuca neriifolia, and Syzygium zeylanicum are restricted to sacred groves. Because of high heterogeneity of sacred groves, many birds and microfungi are also restricted to sacred groves [56]. Every village has, at least, one sacred grove in Kodagu, and the existence of sacred groves in Western Ghats is believed to have more than two millennia [57]. Such a long history of sacred grove values the significance of religion in nature and biodiversity conservation. One of the small states of India namely Sikkim, which lies in another biodiversity hotspot in India, possesses 35 sacred groves mainly associated with monasteries [58]. In biodiversity hotspot countries, over four billion people since belong to the mainstream faiths reveal enormous potential for religion-based biodiversity conservation [59].

The indigenous communities inhabiting various ecosystems across the length and width of India have marked some forest patch as a sacred grove in the vicinity of their villages. This helps to conserve the species diversity across the different ecosystems from tropical to temperate and sub-alpine regions, as many species prefer to grow in specific ecosystems. The scrub forests of Thar Desert in Rajasthan to rain forests of Western Ghats in Kerala and the rich biodiversity of North Eastern States of India are conserved traditionally by earmarking some of the forest areas as the sacred groves.

While Acts and policies have several advantages, they have created conflicts between people and management authorities, especially where the land is brought under protected areas network. There are reports on the degradation of sacred groves, as well $[5,39,58]$. Reasons for this include a change in people's attitude towards them. The newer generations, generally, hardly believe in the methods their ancestors followed to maintain the fragile ecosystems and biodiversity [60]. The official policies are also weakening the local institutions [5]. Besides, the development works, deforestation and encroachment are other possible causes of degradation of sacred groves. Moreover, continuous crisis in centuries-old cultural values and embracing modern civilization has close linkages with present rate of nature's environmental deterioration [61]. Inculcating values of religion, which has saved the nature for posterity, can help in resolving the present impasse in saving the earth.

\subsection{Sacred Species}

Generally, cutting standing green trees is discouraged in Hinduism. Before gathering plants, even for curing diseases, the plants are worshipped and special rituals are performed before and after their collection from its natural habitats. Hinduism teaches to live in harmony with nature and hence advises to respect every element of nature, including plants and animals [62,63]. The Holy Quran of Islam educates its followers to maintain the nature's balance [61]. It further encourages people to grow plants and convert wasteland into greener pastures. Many plants for example Christ's Thorn Jujube (Ziziphus spina-christi), Salvadora persica, and Tamarix aphylla have special mention in the Holy Bible because of their religious importance and sign of joy and happiness (Table 2). Christians have special regard for olive tree (Olea europaea), date palm (Phoenix dactylifera), and Christ's thorn jujube (Ziziphus spina-christi). The name Christ's thorn jujube itself reveals its association with Jesus Christ and is identified with the plant with which Jesus was crowned before his crucifixion [64]. In Jainism, about 24 plant species including Ficus religiosa, F. benghalensis, Saraca asoka, Cedrus deodara and Terminalia bellirica are associated with salvation of 24 Jain Tirthankars, the teaching gods who preach the dharma [65].

Several important plant species such as Saussurea obvallata, Saussurea simpsoniana, Ficus religiosa, Ficus benghalensis, Aegle marmelos, Zanthoxylum armatum, Santalum album and Ocimum sanctum, are symbolized as sacred species in Hinduism. Rudraksha, which is produced by many species of Elaeocarpus is symbolized to the Lord Shiva. The multiple values and high importance of these species have made the people to link these species with religion in order to protect them from overuse and exploitation $[43,51,63]$. The practitioners of Ayurveda use to worship many medicinal plant species before their harvest from nature. Many plant species are medicinal as well as religious and aromatic (Figure 3), and many medicinal and aromatic plant species are worshipped as a symbol of gods and goddesses. Hence, there is a general fear in indigenous communities towards the overexploitation of such plant species [62]. Such a traditional belief in the society is a way of conserving the useful natural resource, which needs to be kept alive in order to sustain the populations of these species for future generations.

There are many examples of associating useful species with local deities in Indian sub-continent. Aegle marmelos is one of the important medicinal and aromatic plants, which is used in various indigenous systems of medicine in India, China, Burma, and Sri Lanka [66,67]. More than 66 ethnobotanical uses of Aegle marmelos are reported within India, of these 48 uses are related to medicinal and aromatic purposes $[63,68]$. Its aromatic cold drink and jam has high demand. Since Aegle marmelos has quite high number of uses and its subsequent over-exploitation has led to associate this species with the Lord Shiva and goddess Lakshmi by Hindus so that people can pay regard to this important useful plant species and avoid its destruction [63]. The three leaflets of Aegle marmelos are assumed to be the symbols of three 'gunas' or attributes (e.g. 'satva', 'rajas' and 'tamas' literally meanings morality, superiority and immorality, respectively), three Gods (Brahma, Vishnu and Mahesh), and three lives (past, present and future). In India, offering leaves of Aegle marmelos by Hindus is an important ritual for worshipping the Lord Shiva. As per Hindu calendar, by every Monday of 'Srawan' month (mind July - mid August) offering its leaves to the Lord Shiva is the most auspicious way of worshipping. On this account, it is planted around many Hindu temples [4,63].

Other important plant species devoted to the Lord Shiva is Zanthoxylum armatum, which has multiple uses as food, medicine and perfumes. Apart from the Shiva, its wood- 
stick is offered to other deities including Vairav, Narshingh, and Guru Gorakh Nath. Hindus believe that Zanthoxylum armatum does not allow impure air in the surrounding areas therefore they use to keep its woodsticks in the house with a view to ward off impure air, including evil spirits [69]. Hindus symbolize three different parts of Ficus benghalensis tree to three wellknown deities, branches to the Shiva, bark to the Vishnu and roots to the Brahma. Because of its association to the trinity gods, no one is allowed to harm this tree. Anthocephelus kadamba, the Kadamba tree, is associated with Lord Krishna who liked to play his flute under this tree. Saraca indica, the Ashoka tree, is a highly medicinal as well as pious tree for both Buddhists and Hindus. Nelumbo nucifera or the Indian lotus is another holy plant as it is believed in Hindu mythology that Brahma, the creator, emerged from the lotus that flowered from the Vishnu's navel. Cocos nucifera is another important plant which is used in most of the auspicious ceremonies of Hindus. It is also tossed over the head of bridegrooms to ward off evil spirits. Ocimum sanctum, a highly medicinal plant, is revered so much by Hindus that the soil around this plant is also considered sacred (Figure 4). A total 38 such holy plant species are worshipped by the community living in Kanyakumari, the southernmost district of Tamil Nadu [70].

Table 2. Some important plants considered sacred because of their mention in holy books and association with different religions.

\begin{tabular}{|l|l|l|l|l|}
\hline S. No & Religion & Sacred plants & Relation with religion & Ref. \\
\hline 1 & Hinduism & $\begin{array}{l}\text { Saussurea obvallata, Ocimum sanctum, Ficus } \\
\text { religiosa, F. benghalensis, Aegle marmelos, } \\
\text { Zanthoxylum armatum, Elaeocarpus ganitrus }\end{array}$ & Symbol of gods and goddesses & Kala, 2006, 2010a \\
\hline 2 & Christians & $\begin{array}{l}\text { Olive tree (Olea europaea), date palm (Phoenix } \\
\text { dactylifera), Christ's Thorn Jujube (Ziziphus spina- } \\
\text { christi) }\end{array}$ & $\begin{array}{l}\text { Olive is symbol of peace. } \\
\text { Date palm being a simple tree is honored } \\
\text { as a Sunday Palm, and it is used to } \\
\text { welcome the Jesus Christ. }\end{array}$ & $\begin{array}{l}\text { Dafni et al., 2005; } \\
\text { David, A. (pers. comm.) }\end{array}$ \\
\hline 3 & Islam & $\begin{array}{l}\text { Christ's Thorn Jujube (Ziziphus spina-christi), } \\
\text { Salvadora persica, Tamarix aphylla }\end{array}$ & Frequent mention in holy book Quran & $\begin{array}{l}\text { Dafni et al., 2005; } \\
\text { Marwat et al., 2008 }\end{array}$ \\
\hline 4 & Buddhism & $\begin{array}{l}\text { Terminalia chebula, Ficus religiosa, F. } \\
\text { benghalensis }\end{array}$ & Associated with Lord Buddha & Kala, 2002, 2005c \\
\hline 5 & Jainism & $\begin{array}{l}\text { Ficus religiosa, F. benghalensis, Saraca asoka, } \\
\text { Cedrus deodara, Terminalia bellirica }\end{array}$ & $\begin{array}{l}\text { Linked with salvation of Tirthankars } \\
\text { (teaching gods who preach the dharma) }\end{array}$ & Jain and Kapoor, 2007 \\
\hline
\end{tabular}

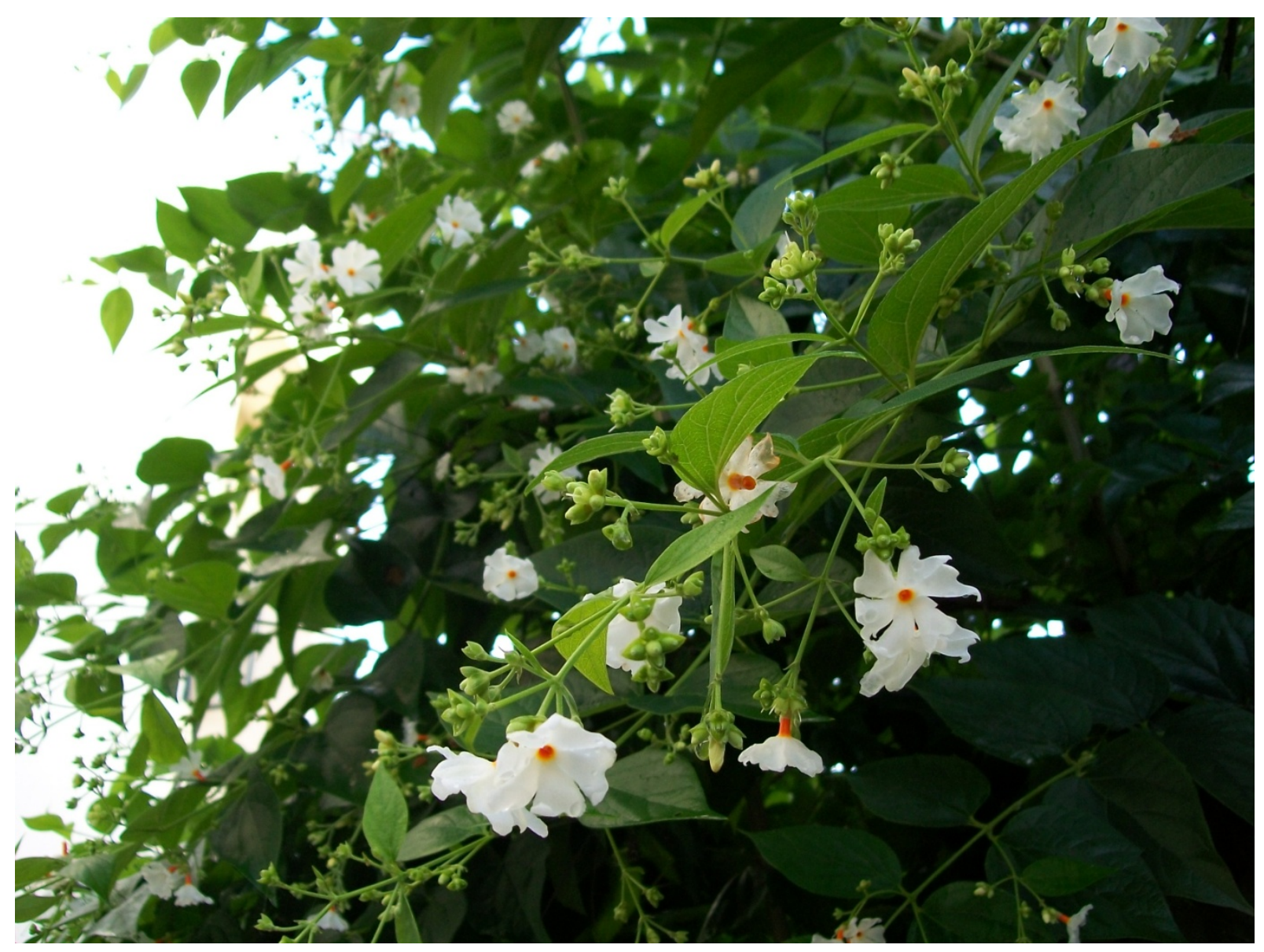

Figure 3. Parijaat (Nyctanthes arbor-tristis); a medicinal aromatic and religious plant - Photo by Chandra Prakash Kala 


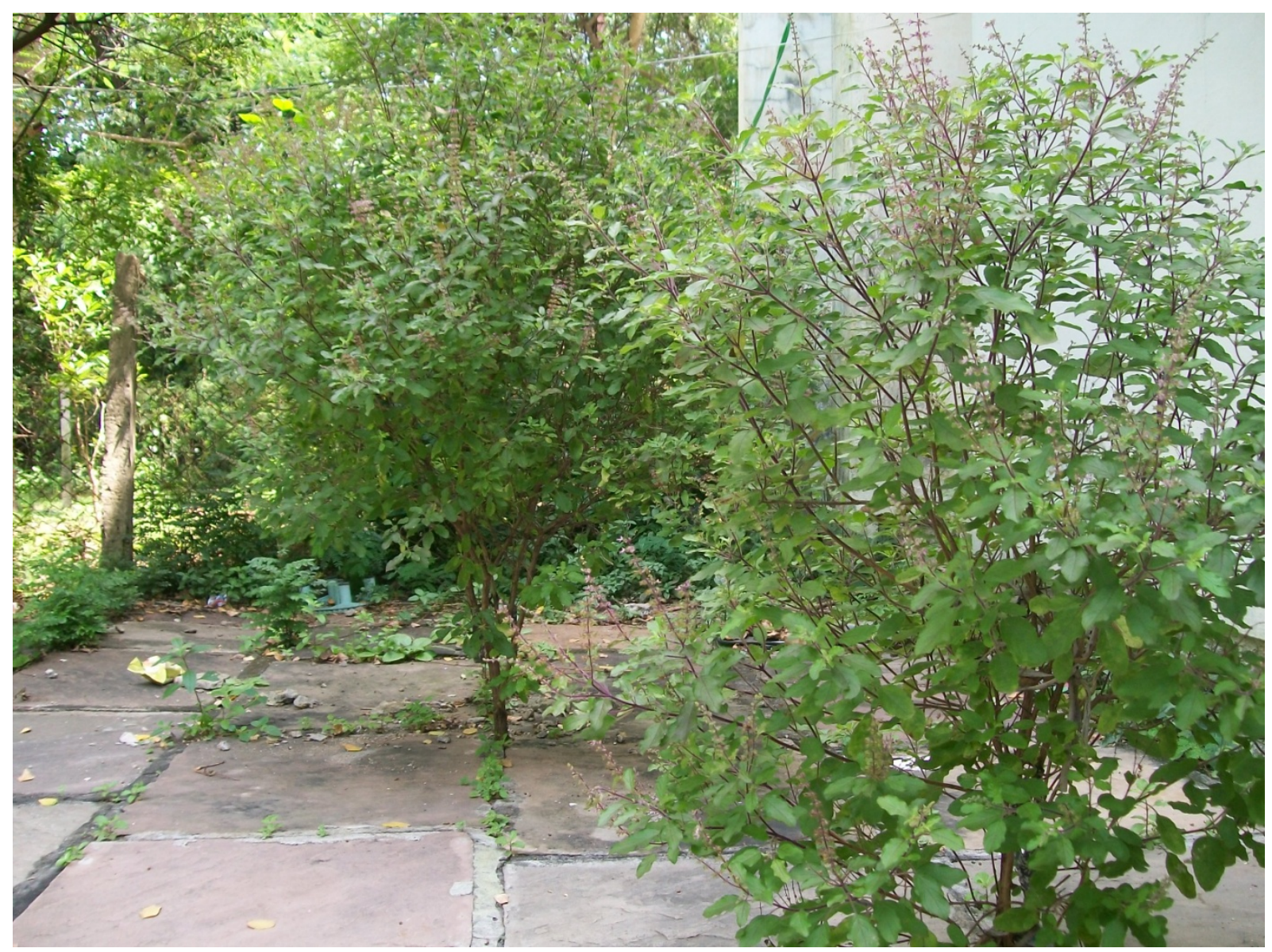

Figure 4. Tulsi (Ocimum sanctum); a medicinal aromatic and religious plant - Photo by Chandra Prakash Kala

The traditional herbal healers used to collect the required plant parts of many plant species at particular season, and they chant some 'mantras' (hymns) just before collection of fruits, leaves and bark for preparing medicine. The traditional healers also avoid disclosing many medicinal properties of the plant species in view of reducing the overwhelming pressures of their collection [63]. While transferring knowledge to next generation, many herbal healers take oath from their disciples for not misusing the knowledge on medicinal plants [71]. Earlier, such conservation oriented practices of important plant species was enforced by traditional beliefs and customs, which are still alive today, though in fragments, on the name of traditional cultures.

There are interconnections between sacred species and sacred landscape that help in conservation of useful species. Origanum vulgare grows in and adjacent of the Badrinath valley in the Indian Himalaya has special cultural and conservation significance, as it is offered to the Lord Badrinath. Similarly the Saussurea obvallata, $S$. gossypifora and S. simpsoniana grow above $3800 \mathrm{~m}$ elevation in the sacred high altitude mountains of the Himalaya and collection of these species, before and after a few days traditionally allocated for collection, is strictly prohibited under the customary laws [4]. Prosopis cineraria, locally called as Khejri in deserts of Rajasthan state of India, is treasured for its moisture-retaining properties, and it is not axed even if it comes between the constructions. Bishnoi community of this state is also well known for protection of wildlife species, especially the black buck [72].
Many animal species are linked with deities in Hinduism. Lord Shiva has infinite attributes, as the snakes coiled around his neck, and his attire is tiger skin. His association with bull make people to respect animals. Eagle is known to carry Lord Vishnu, bull to Shiva and lion to Durga. Snakes, especially cobras are worshipped in some specific days, such as Nagpanchami. Monkey is associated with lord Hanuman, elephant to lord Ganesha, peacock to Saraswati, swan to Brahma, and cow is a holiest animal for Hindus [73,74]. Fox, weasel, hedgehog and snake are sacred for people living in Peking region of China, though they do not consider all individuals of these species are sacred. The peculiar behaviour of an individual makes it sacred and hence it is worshipped and cannot be hunted [75].

Muslims do believe in nature conservation and hence they do advocate for animal protection, as and when required [15]. The Islamic clerics in Indonesia have issued a fatwa (literally means a code of law under which infringements are considered immoral and illegal) to protect endangered animals. This is a unique strategy, which can play an important role for saving animals. Indonesia is known for Asian elephant and there is rampant hunting of elephants for ivory. The fatwa helps to protect such threatened species [76]. In Misali Island, west of Pemba, Tanzania, the use of dynamite for fishing by Muslim fishermen had eroded the turtle nesting sites. When government efforts for protecting such sites could not harness any result, the Imams came forward to convey the fishermen community that according to Quran use of dynamite for fishing is illegal. The fishermen responded 
immediately and stopped the use of dynamites for fishing $[77,78]$.

Jainism considers that every animal, plant and human has a soul and therefore they should be treated with respect [79]. Similarly, Buddhists love and pay respect to all living beings as per their religious beliefs. Buddhists monks in the Trans-Himalayan Tibetan Plateau make sure that the snow leopard, a highly endangered large cat species, may not be poached [12]. Any animal or plant species which is attributed to some religion is well known to the community hence once the species become rare or endangered it is observed promptly by the community. However, the species which does not enjoy any religious symbol, even being extremely rare may be hardly noticed by the community.

\subsection{Cultures and Conservation}

Approximately 5000 distinct indigenous cultural groups are known to occur across the different climatic zones, worldwide. They contribute $4 \%$ to the world's population yet they represent $95 \%$ of the world's cultural diversity [80]. Each cultural group shares a common religion, moral values, belief systems and relationship to the territory they inhabit. Interestingly, most of the biodiversity rich areas, which hold almost $80 \%$ of the world's biodiversity, coincide with areas occupied by these indigenous communities [80]. Nearly $20 \%$ of world population live within the biodiversity hotspots, which span over $12 \%$ of Earth's terrestrial surface [81]. These communities have their own institutions of knowledge on natural resources and ways to transfer of such knowledge through generations. Biodiversity conservation may not be an isolated or segmented concept to these people rather it is tangled in their lives. The conservation areas such as sacred groves are integral parts of their homeland. Respecting their organizational structure that provides answers through keen observations of specific localities and resources along with philosophies and methods of acquiring and communicating knowledge helps in maintaining nature and natural resources [82].

The practices of shifting cultivation, which is also known as 'jhum' or slash and burn agriculture and still practiced by many indigenous communities, anchor rich traditional ecological knowledge within the forested landscapes $[83,84]$. Small scale slash-burn disturbances under shifting cultivation not only help to maintain but also enhance the forest biological diversity [85]. Diverse human-managed agricultural systems along with associated natural ecosystems such as home gardens and traditional multi-species plantation systems provide a unique ethnic-specific identity to the landscape. However, the shortening of agricultural cycles due to external pressures on the forests not only declines the system's stability and resilience but also disrupts social system and biodiversity [86].

Biodiversity, including agricultural crops, being embedded in the cultures, it is reproduced and conserved through cultural activities as performed during festivals and rituals [87]. In indigenous communities, the plantations and harvesting practices begin with festivals and rituals. Besides, through these festivals and rituals seed selection and propagation tests are conducted in order to understand the viability of seeds and propagules. These tests are quite reliable and systematic as they have the long history of conservation and preservation of rich agro-biodiversity. Profane seeds are removed through these tests as it is believed that such seeds fragment agricultural ecosystems and break down relationships that are responsible for sustainable production. Sacredness of seeds and their diversity is embedded in the worldview of indigenous communities [88]. These traditional beliefs and practices have conserved the seeds through generations, and so that the agro-biodiversity.

Indigenous communities, worldwide, follow many traditional practices for collection of natural resources, which remain important tool for conservation. Depending on the availability of plant parts due to various phenophases the harvesting mechanism is designed. Traditional herbal healers in most of the communities mainly adopt religious approaches and selective harvesting of plants used as medicine [62,89]. Before collection of many plant species for therapeutic purpose special rituals are performed by the practitioner of Ayurveda, the well-known herbal system of medicine in India. Mainly the mature plants are recommended to harvest. Underground plant parts (root and rhizomes) of perennials are generally gathered after 2 or 3 years of growth. Tubers and bulbs of the annual species are collected at the end of the flowering or fruiting. Young leaves of medicinal plants are gathered throughout the growing period to maximize the quality of active compounds. When the whole herb is required for medicine, the herb is collected at the beginning of the flowering stage. Fruits and seeds of medicinal plants are collected when mature. The bark is collected when trees and shrubs begin to bud in the spring and after leaves drop in the autumn $[90,91]$.

In the Himalayan region of Nepal, young leaves, if required, are harvested in the spring, flowers and mature leaves in the summer, and fruits, seeds and rhizomes are collected in the autumn [4]. In Tibetan Medicine System, the harvesting of medicinal plants is determined by the cultural and religious calendar. In late September or early October, when most of the alpine plants complete their life cycle, Amchi (medical practitioners of Tibetan Medical System) collect plants for preparing medicine $[92,93]$. It was perceived that the mistaken identity of plant during collection, particularly of plants with phenotypic similarity, might lead to accidental poisoning; therefore only the experienced herbal healers used to collect the medicinal plants. After collection, proper care was taken to dry and process the material.

In north-western North America, the techniques for collection of plant parts as adopted by the indigenous communities are based on the fact that almost all resource plant species are perennials. Therefore, individual plant is not usually destroyed except in case of requirement of an entire tree for the purpose of construction $[82,94]$. The required plant parts are only harvested from such plants having regeneration capacity. While harvesting bark of western red cedar and yellow cedar, they ensure that the tree must continue to live as they harvest less than one third of the bark from the tree's circumference. The community follows such norms as it is deeply embedded in their culture and belief system that teaches the notion of 
respect for all life-forms and the land itself [82]. The indigenous practices of resource use, even the combination of fire management and agriculture, nurture the soil rather than simply mine it [95]. There are number of cultural practices which still help in multiple species management, succession management, resource rotation and mosaics of landscape management [83].

\subsection{Religion-based Conservation Model}

In Uttarakhand state of India, the Badrinath is one of the most sacred shrines of Hindus located at $3100 \mathrm{~m}$ a.m.s.l. More than 600,000 pilgrims visit annually to the Lord Vishnu in Badrinath shrine, which is almost in the middle of $4 \mathrm{~km}^{2}$ Badrinath valley. The natural and anthropogenic disturbances had declined the vegetation wealth in this valley and at the end of $20^{\text {th }}$ century tree species had vanished from most parts of this valley [96]. Loss of tree species has not only adversely affected the scenic beauty and aesthetic values attached with the Badrinath shrine but also has invited calamities in the form of heavy soil erosion, flooding, and environmental degradation. Many sacred plant species, including Origanum vulgare, which is offered to the Lord Badrinath and Betula utilis, grow in this valley but due to rampant collection it was declined severely.

The researchers from the GB Pant National Institute of Himalayan Environment and Sustainable Development, Almora after initial scrutiny selected 20 tree species for restoration in Badrinath valley, which include Betula utilis, Prunus cornuta, Taxus baccata, Abies pindrow, and Hippophae salicifolia. Nursery of these species was prepared and after 2 years hardening and acclimatization of tree seedlings, they were planted in the Badrinath valley. Further, in view of inculcating the sense of belongings and sentiments of local people, visitors, priests and pilgrims were approached to make them aware on the importance of selected species and to persuade them for their effective participation in the plantation programs. The seedlings were planted by organizing Plant Distribution Ceremonies with the help of chief priest of Badrinath shrine. The involvement of chief priest and his decrees to the pilgrims and other people on the importance and sanctity of plantation made these ceremonies quite auspicious. Through these rituals the seedlings were acknowledged as the holy objects, and hence it helps in making a social and cultural fencing for protection of plantations [96,97]. Such models, if extended across the globe, may help to accelerate the pace of biodiversity conservation and, at the same time, may reduce the conflicts related with conservation.

The reciprocal relationship between humans and the rest of the nature, especially in terms of nature conservation, may be further explored by applying psychological principles and theories in order to comprehend and to apply diligently the human aspects of nature conservation [98]. The conservation philosophy, which demands constructive approach in dealing with communities, may be applied through religious beliefs as such beliefs are inseparable from the communities. After all the fate of conservation is in the hands of all social groups, especially the indigenous communities who still live in remote and wilderness areas and have been the custodian of such resources, historically. Respecting and recognizing their knowledge and belief systems may help to conserve the nature and natural resources.

The present forms of various landscapes across the world are the products of social and economic systems. In the race of increasing forest productivity and high value timber production, the native biodiversity is being adversely impacted due to promotion of monoculture plantations. With the development of methodically designed silvicultural theory, which advices to manage forests primarily based on natural principles, provides space for cultural values apart from achieving the economic and ecological targets [99]. Many traditional practices of forest management and nature conservation, including long rotation ages and selective harvesting practices, are being included in the government policies realizing the merits of such practices [52]. The argument which suggests that if the forests are left undisturbed they will certainly regenerate [100] undermines the importance of extinct, near extinct and restricted range species. It is obvious that attempts can only be made for the conservation of such species which exists. If the species is no more the theory which suggests that 'let the nature takes it course' will not help in returning the extinct species. It is, therefore, good to keep open mind for analysing all approaches for long-term conservation.

\section{Conclusion}

The importance of sacred groves, sacred landscapes and sacred species should not be viewed merely in the economic and livelihood perspectives but these entities need to be respected as the historical evidence of human relationship with nature and its components. At present, many causes of biodiversity loss are discovered, which include increasing disconnection of urban population from nature. Revitalizing traditional human connections with the natural world is a need of hour in view of respecting and conserving nature. Since religion changes and influences fundamental values of human beings, it has been supporting nature conservation since antiquity. As Albert Einstein believed that the serious scientific workers are profoundly religious people in the present materialistic age, the religion-based belief system can save our planet from the ongoing degradation. The spiritual context of nature conservation, which is ignored in satisfying human needs and quality of life, must be recognized without further delay. There are numerous temples, gurudwaras, churches and mosques across the countries in the planet earth. A large number of devotees visit these sacred places every day to pay homage. If the priests, clerics, granthi (sikh priest), molvi (Muslim cleric) and Dalai Lama issue decrees to their respective devotees for nature conservation, it is expected that the outcome will be fruitful. The religion-based conservation models need to be developed. In the present era of global warming and anthropogenic climate change the values of religion, if injected wisely, can help to resolve the problems and facilitate in maintaining the nature and natural resources. 


\section{Acknowledgements}

The author acknowledges the support extended by the Indian Institute of Forest Management, Bhopal.

\section{References}

[1] Einstein, A. 1949. The World as I See It. Philosophical Library, New York.

[2] Iltis, H. 1980. The Urban Setting: Man's Need for Open Spaces. Connecticut College, New London.

[3] Kellert, S.R. and Wilson, E.O. 1995. The Biophilia Hypothesis Island Press, Washington DC, USA.

[4] Kala, C.P. 2010. Ethnobotanical and ecological approaches for conservation of medicinal and aromatic plants. Acta Horticulturae, 860: 19-26.

[5] Brandt, J.S., Butsic, V., Schwab, B., Kuemmerle, T. And Radeloff, V.C. 2015. The relative effectiveness of protected areas, a logging ban, and sacred areas for old-growth forest protection in southwest China. Biological Conservation, 181: 1-8.

[6] Boyd, J.M. 1984. The role of religion in conservation. Environmentalist, 4 (7): 40-44.

[7] Avise, J.C., Hubbell, S.P. and Ayala, F.J. 2008. In the light of evolution II: Biodiversity and extinction. PNAS, 105: 1145311457.

[8] Lawton, J. H., and May, R.M. 1996. Extinction Rates. Oxford University Press.

[9] Miller, J.R. 2005. Biodiversity conservation and the extinction of experience. Trends in Ecology and Evolution, 20 (8): 430-434.

[10] Barlow, J. Gardner, T.A., Lees, A.C., Parry, L., Peres, C.A. 2012. How pristine are tropical forests? An ecological perspective on the pre-Columbian human footprint in Amazonia and implications for contemporary conservation. Biological Conservation, 151: 45-49.

[11] Mori, A.S., Spies, T.A., Sudmeier-Rieux, K. and Andrade, A. 2013. Reframing ecosystem management in the era of climate change: Issues and knowledge from forests. Biological Conservation, 165: 115-127.

[12] Li J, Wang D, Yin H, Zhaxi D, Jiagong Z, Schaller GB, Mishra C, McCarthy TM, Wang H, Wu L, Xiao L, Basang L, Zhang Y, Zhou Y, Lu Z. 2014. Role of Tibetan Buddhist monasteries in snow leopard conservation. Conservation Biology, 28 (1): 87-94.

[13] Liu, H., Xu, Z.F. and Wang, J.X. 2002. Practice of conserving plant diversity through traditional beliefs: A case study in Xishuangbanna, southwest China. Biodiversity and Conservation, 11: 705-713.

[14] Sponsel, L.E. 2012. Spiritual Ecology: A Quiet Revolution, ABCCLIO Publication, 284 pages.

[15] Jusoff, K and Siti, A.A.S. 2011. Environmental Sustainability: What Islam Propagates? World Applied Sciences Journal, 12: 46-53.

[16] Katz, K. 2003. Legitimizing Jordan as the Holy Land: Papal Pilgrimages -- 1964, 2000. Comparative Studies of South Asia, Africa and the Middle East, 23 (1): 181-189.

[17] Weiss, J. 2013. Pope Francis Calls for Amazon Conservation. World Wildlife Fund Washington, DC. http://www.worldwildlife.org/stories/pope-francis-calls-foramazon-conservation.

[18] Horster, M. 2011. Religious Landscape and Sacred Ground: Relationships between Space and Cult in the Greek World. Revue de l'histoire des religions, 4: 435-458.

[19] Hughes, J.D. 1990. Pan's Travel: Environmental Problems of the Ancient Greek and Romans. Johns Hopkins University Press, Baltimore.

[20] Vest, J.H.C. 1985. Will of the Land: Wilderness among Primal Indo-Europeans. Environmental Review, 9 (4): 323-329.

[21] Woff, R. 2003. A Pocket Dictionary of Greek and Roman Gods and Goddesses. The British Museum Press, London. 48 pp.

[22] Earhart, H.B. 1989. Mount Fuji and Shugendo. Japanese Journal of Religious Studies, 16: 205-226.

[23] Blake, K. 2008. Imagining heaven and earth at Mount of the Holy Cross, Colorado. Journal of Cultural Geography, 25 (1): 1-30.

[24] Harahsheh, S., Morgan, M., \& Edwards, J. 2007. The influence of religious belief on destination image: The case of the Hashemite kingdom of Jordan. International Journal of Management Cases, 9 (3-4): 63-73.

[25] Harbison, P. 1992. Pilgrimage in Ireland: the monuments and the people. Syracuse University Press

[26] Lane, B. C. 2001. Giving voice to place: Three models for understanding American sacred space. Religion \& American Culture, 11 (1): 53-81.

[27] Sundstrom, L. 1997. The Sacred Black Hills: An Ethnohistorical Review. Great Plains Quarterly, 17 (3/4): 85-212.

[28] Knight, C. 2009. Between the Profane World and the Spirit World: A Comparison of the Conceptualisation of Uplands and Mountains in Maori and Japanese Folklore. New Zealand Journal of Asian Studies, 11(2): 96-114.

[29] Shackley, M. 1998. A golden calf in sacred space?: The future of St Katherine's monastery, Mount Sinai (Egypt). International Journal of Heritage Studies, 4(3-4): 124-134.

[30] Kala, C.P. 2014. Deluge, disaster and development in Uttarakhand Himalayan region of India: Challenges and lessons for disaster management. International Journal of Disaster Risk Reduction, 8: 143-152.

[31] Armour, P. G. 2006. Counting boulders and measuring mountains. Communications of the ACM, 49 (1): 17-20.

[32] Anderson, D.M., Salick, J., Moseley, R.K., Xiaokun, O. 2005. Conserving the Sacred Medicine Mountains: A Vegetation Analysis of Tibetan Sacred Sites in Northwest Yunnan. Biodiversity and Conservation, 14 (13): 3065-3091.

[33] Salick, J., Amend, A., Anderson, D., Hoffmeister, K., Gunn, B., and Zhendong, F. 2007. Tibetan sacred sites conserve old growth trees and cover in the eastern Himalayas. Biodiversity and Conservation, 16 (3): 693-706.

[34] Allan, J.D. and Flecker, A.S. 1993. Biodiversity conservation Running Waters: Identifying the major factors that threaten destruction of riverine species and ecosystems. BioScience, 43 (1): 32-43.

[35] Yardenit 2015. The Jordan River. Yardenit - Kibbutz Kinneret Jordan Valley, Israel. https:/www.yardenit.com/baptism/jordanriver.

[36] Belhassen, Y., Caton, K. and Stewart, W.P. 2008. The search for authenticity in the pilgrim experience. Annals of Tourism Research, 35 (3): 668-689.

[37] Becker, N., Helgeson, J. and Katz, D. 2014. Once there was a river: a benefit-cost analysis of rehabilitation of the Jordan River. Regional Environmental Change, 14 (4): 1303-1314.

[38] Gadgil, M. and Vartak, V.D. 1976. Sacred groves of Western Ghats of India. Ecological Botany, 30: 152-160.

[39] Khan, M.L., Khumbongmayum, A.D. and Tripathi, R.S. 2008. The sacred groves and their significance in conserving biodiversity: An overview. International Journal of Ecology and Environmental Sciences, 34 (3): 277-291

[40] Kala, C.P. 2015. Revitalizing sacred groves. Down to Earth. http://www.downtoearth.org.in/content/revitalising-sacred-groves.

[41] Tokarev, S. 1989. History of Religion. Progress Publishers, Moscow.

[42] Hughes, J.D. and Swan, J. 1986. How much of the earth is sacred space? Environmental Review, 10 (4): 247-269.

[43] Gowda, B. 2006. Sacred Plants. Kalpataru Research Academy, Bangalore.

[44] Balzer, M.M. 1999. The Tenacity of Ethnicity: A Siberian Saga in Global Perspective. The Princeton University Press, New Jersey.

[45] Gadgil, M., Berkes, F. and Folke, C. 1993. Indigenous Knowledge for Biodiversity Conservation. A Journal of the Human Environment, 22: 151-156.

[46] Malhotra, K.C., Ghokhale, Y., Chatterjee, S. and Srivastava, S. 2001. Cultural and Ecological Dimensions of Sacred Groves in India. INSA, New Delhi.

[47] Ramachandran, B. 1999. Significance of Kavu-A Note on the Sacred Grove of Kerala in Eco-Cultural Context. Journal of Human Ecology, 10 (4): 285-288.

[48] Joshi, P. and Shrivastava, Y. 2000. Drops of Nature Conservation - Sacred Grove. Journal of Human Ecology, 11 (5): 327-330.

[49] Xaxa, V. 1991. Oraons: Religion, Custom and Environment. In: G. Sen, Ed., Indigenous Vision, Saga Publication, New Delhi, pp 101-109.

[50] Chandran, M.D.S. and Hughes, J.D. 1997. The sacred groves of south India: Ecology, traditional communities and religious change. Social Compass, 44 (3): 413-427. 
[51] Kala, C.P. 2011. Traditional ecological knowledge, sacred groves and conservation of biodiversity in the Pachmarhi Biosphere Reserve of India. Journal of Environmental Protection, 2 (7): 967-973.

[52] Trosper, R.L. 2007. Indigenous influence on forest management on the Menominee Indian Reservation. Forest Ecology and Management, 249: 134-139.

[53] Byers, B.A., Cunliffe, R.N. and Hudak, A.T. 2001. Linking the Conservation of Culture and Nature: A Case Study of Sacred Forests in Zimbabwe. Human Ecology, 29 (2): 187-218.

[54] Brandis, D. 1897. Indian Forestry. Oriental University Institute. Woking, UK, pp 2-16.

[55] Mishra, M.K. 2009. Sacred worldview in tribal memory: sustaining nature through cultural actions. Language \& Ecology, 2 (4): 1-7.

[56] Bhagwat, S.A., Kushalappa, C.G., Williams, P.H. and Brown, N.D. 2005. The role of informal protected areas in maintaining biodiversity in the Western Ghats of India. Ecology and Society 10 (1): 8 .

[57] Gadgil, M. 1992. Conserving biodiversity as if people matter: a case study from India. Ambio 21: 266-270.

[58] Das, S.S. 2005. Kabi sacred grove of North Sikkim. Current Science, 89 (3): 427-428.

[59] Bhagwat, S.A., Dudley, N. and Harrop, S.R. 2011. Religious following in biodiversity hotspots: challenges and opportunities for conservation and development. Conservation Letters, 4: 234-240.

[60] Kala, C.P. 2012. Traditional ecological knowledge and conservation of ethnobotanical species in the buffer zone of Pachmarhi Biosphere Reserve, Madhya Pradesh. Indian Institute of Forest Management, Bhopal. 194 pp.

[61] Kamla, R., Gallhofer, S. and Haslam, J. 2006. Islam, nature and accounting: Islamic principles and the notion of accounting for the environment. Accounting Forum, 30 (3): 245-265.

[62] Kala, C.P. 2005. Current status of medicinal plants used by traditional Vaidyas in Uttaranchal state of India. Ethnobotany Research and Applications, 3: 267-278.

[63] Kala, C.P. 2006. Ethnobotany and ethnoconservation of Aegle marmelos (L.) Correa. Indian Journal of Traditional Knowledge, 5 (4): 537-540.

[64] Dafni, A., Levy, S., and Lev, E. 2005. The ethnobotany of Christ's Thorn Jujube (Ziziphus spina-christi) in Israel. Journal of Ethnobiology and Ethnomedicine, 1: 1-11.

[65] Jain, S.K. and Kapoor, S. 2007. Divine botany-universal and useful but under explored traditions. Indian Journal of Traditional Knowledge, 6 (3): 534-539.

[66] Kritikar, K.R. and Basu, B.D. 1984. Indian Medicinal Plants. Vol I-IV, Bishen Singh Mahendra Pal Singh, Dehradun.

[67] Kala, C.P., Farooquee, N.A. and Dhar, U. 2004. Prioritization of medicinal plants on the basis of available knowledge, existing practices and use value status in Uttaranchal, India. Biodiversity and Conservation, 13 (2): 453-469.

[68] Jain, S.K. 1991. Dictionary of Indian Folk Medicine and Ethnobotany. Deep Publications, New Delhi, India.

[69] Kala, C.P. 2010. Assessment of availability and patterns in collection of Timroo (Zanthoxylum armatum DC.): A case study of Uttarakhand Himalaya. Medicinal Plants, 2 (2): 91-96.

[70] Lohidas, J., Pappa, V.R. and Simi, N. 2014. Role of holy plants in health care system of the people in Kanyakumari district, Tamil Nadu, India. Plant Archives, 14 (1): 81-86.

[71] Kala, C.P. 2012. Forgotten healers. Down to Earth, 21: 46-47.

[72] Kala, M. and Sharma, A. 2010. Traditional Indian beliefs: a key towards sustainable living. The Environmentalist, 30 (1): 85-89.

[73] Krishna, N. 2010. Sacred Animals of India. Penguin Books, New Delhi, India.

[74] Kala, C.P. 2015. Nanda's Neelkanth. Partridge Publishing, Bloomington, USA. $340 \mathrm{pp}$.

[75] Wei-Tsu, L. 1948. On the cult of the four sacred animals in the neighbourhood of Peking. Folklore Studies, 7: 1-94.

[76] Chambers, B. 2014. Religion and Conservation Do Mix. Inter Press Service News Agency. http://www.ipsnews.net/2014/03/religion-conservation-mix/.
[77] Gambrill, A. (2011). From Practice to Policy to Practice: Connecting Faith and Conservation in Africa, International Resources Group for US AID Bureau for Africa. Washington, DC. http://www.rmportal.net/library/content/from-practice-to-policyto-practice-connecting-faith-and-conservation-in-africa/.

[78] Awoyemi, S.M., Gambrill, A., Ormsby, A. and Vyas, D. 2012. Global Efforts to Bridge Religion and Conservation: Are They Really Working? Topics in Conservation Biology, Povilitis, T. (ed.), InTech, Rijeka, Croatia. pp 97-110.

[79] Hall, M., Grim, J. and Tucker, M.E. 2009. Need for religions to promote values of conservation. Nature, 462 (10): 720.

[80] Sobrevila, C. 2008. The Role of Indigenous Peoples in Biodiversity Conservation: The Natural but Often Forgotten Partners. The International Bank for Reconstruction, Washington DC, USA. 84 pp.

[81] Cincotta, R.P., Wisnewski, J. and Engelman, R. 2000. Human population in the biodiversity hotspots. Nature, 404 (6781): 990-992.

[82] Turner, N.J., Ignace, M.B. and Ignace, R. 2000. Traditional Ecological Knowledge and Wisdom of Aboriginal Peoples in British Columbia. Ecological Applications, 10 (5): 1275-1287.

[83] Berkes, F., Colding, J. And Folke, C. 2000. Rediscovery of traditional ecological knowledge as adaptive management. Ecological Applications, 10 (5): 1251-1262.

[84] Cairns, M. 2015. Shifting Cultivation and Environmental Change: Indigenous People, Agriculture and Forest Conservation. Routledge, New York.

[85] Ramakrishnan, P.S., Saxena, K.G., Rao, K.S. 2006. Shifting Agriculture and Sustainable Development of north-eastern India: Tradition in Transition. UNESCO and Oxford \& IBH, 495 pp.

[86] Ramakrishnan, P.S. 2007. Traditional forest knowledge and sustainable forestry: A north-east India perspective. Forest Ecology and Management, 249: 91-99.

[87] Kala, C.P., Dollo, M., Farooquee, N.A. and Choudhury, D.C. 2008 Land-use management and wet-rice cultivation (Jebi Aji) by the Apatani people in Arunachal Pradesh, India Traditional knowledge and practices. Outlook on Agriculture, 37 (2): 125-129.

[88] Shiva, V. 1992. Women's Indigenous Knowledge and Biodiversity Conservation. India International Centre Quarterly, 19 (1/2): 205-214.

[89] Kala, C.P. 2005. Ethnomedicinal botany of the Apatani in the Eastern Himalayan region of India. Journal of Ethnobiology and Ethnomedicine, 1 (11): 1-12.

[90] Kaul, M.K. 1997. Medicinal Plants of Kashmir and Ladakh. Indus Publishing Company, New Delhi, India.

[91] Kala, C.P. 2002. Medicinal Plants of Indian Trans-Himalaya. Bishen Singh Mahendra Pal Singh, Dehradun, India.

[92] Ghimire, S.K., McKey, D. and Aumeeruddy-Thomas, Y. 2004. Heterogeneity in ethnoecological knowledge and management of medicinal plants in the Himalayas of Nepal: Implications for conservation. Ecology and Society, 9 (3): 6.

[93] Kala, C.P. 2005. Health traditions of Buddhist community and role of amchis in trans-Himalayan region of India. Current Science 89: 1331-1338.

[94] Turner, N.J. and Loewen, D.C. 1998. The original" free trade": exchange of botanical products and associated plant knowledge in northwestern North America. Anthropologica, 40 (1): 49-70.

[95] Clement, C.R., Junqueira, A.B., 2010. Between a pristine myth and an impoverished future. Biotropica, 42: 534-536.

[96] Dhyani, P.P. 1998. Badrivan programme at Badrinath Dham: An innovative model for restoration of degraded lands and biodiversity conservation. p. 387-405. In: GBPIHED, Research for Mountain Development: Some Initiatives and Accomplishments. Gyanodaya Prakashan, Nainital, India.

[97] Bernbaum, E. 1996. Pilgrims plant a forest. People and the Planet, 5 (1): 11.

[98] Saunders, C.D. 2003. The Emerging Field of Conservation Psychology. Human Ecology Review, 10 (2): 137-149.

[99] Johann, E. 2007. Traditional forest management under the influence of science and industry: The story of the alpine cultural landscapes. Forest Ecology and Management, 249: 54-62.

[100] Willis, K.J., Gillson, L., Brncic, T.M., 2004. How "virgin" is virgin rainforest? Science, 304: 402-403. 